\title{
Temperature and Salinity Effects on the Acute Toxicity of Cadmium to Laomedea loveni (Hydrozoa)*
}

\author{
H. Theede, N. Scholz and H. Fischer \\ Institut für Meereskunde an der Universität Kiel, Diisternbrooker Weg 20, D-2300 Kiel 1, Federal Republic of Germany
}

\begin{abstract}
The hydroid polyp Laomedea loveni Allm. responds to very low cadmium concentrations in sea water $\left(\mu \mathrm{g}\right.$ Cd $l^{-1}$ range). The acute toxicity of $\mathrm{Cd}$ is strongly modified by abiotic factors. At low temperatures and high salinities $L$. loveni is more tolerant to $\mathrm{Cd}$ contamination than at the reverse temperature-salinity combinations. The $\mathrm{Cd}$ concentration causing irreversible retraction of $50 \%$ of the hydranths after a 7 -day exposure of polyp colonies ( $7 \mathrm{~d} \mathrm{ED}_{50}$ ) varies from $3 \mu \mathrm{g} \mathrm{l}^{-1}\left(\mathrm{at} 17.5^{\circ} \mathrm{C}\right.$ and $10^{\circ} / \mathrm{S}$ ) to $80 \mu \mathrm{gl}^{-1}$ (at $7.5^{\circ} \mathrm{C}$ and $25 \% \mathrm{~S}$ ). The accumulation of $\mathrm{Cd}$ increases at higher temperatures.
\end{abstract}

\section{INTRODUCTION}

Cadmium is, like mercury, one of the most toxic heavy metals known. In many rivers (Förstner and Müller, 1974) and in coastal areas this metal is present in high concentrations. Large deposits occur especially in sediments and at the higher levels of food webs (Phillips, 1977). The amount of cadmium in the sediment of the Bight of Eckernförde (Federal Republic of Germany) has increased sevenfold over the last 130 years. Compared to other heavy metals this is the highest rate of increase in this area (Erlenkeuser et al., 1974). For details consult 'Marine Ecology', Volume V (in press).

Organismic resistance to cadmium varies widely. Larvae of oysters and crustaceans (Connor, 1972) and fish embryos (Pickering and Gast, 1972) are considerably more sensitive to heavy metals than are the respective adult stages.

Experimental determinations of tolerance limits must take into account abiotic environmental factors. In fresh waters, cadmium tolerance limits are influenced by the degree of hardness (Pickering and Henderson, 1966); in marine waters, by salinity and temperature (e.g. Eisler, 1971; Olson and Harrel, 1973; von Westernhagen et al., 1974, 1975; Jones, 1975; Rosenberg and Costlow, 1976). These relationships

\footnotetext{
- Financially assisted by the 'Deutsche Forschungsgemeinschaft' (Grant TH 158/9).

Please address requests for reprints to N. Scholz
}

may be of importance for in-situ survival, especially in estuaries and coastal areas. We have investigated the effects of temperature and salinity on the toxicity of cadmium in marine Hydrozoa. These animals are particularly suitable for such investigations because of their high sensitivity to heavy metals (Karbe, 1972). The responses of marine organisms to environmental factors have been reviewed exhaustively in 'Marine Ecology', Volume I. Temperature and salinity effects on invertebrates received attention from Kinne (1970, 1971).

\section{MATERIAL AND METHODS}

The hydroid polyp Laomedea loveni Allm., used as test organism in this study, is boreal and euryhaline. Its distribution in the Baltic Sea extends as far as the Aland islands and the Gulf of Finland (Vervoort, 1946). The lower salinity limit is about $4-7 \% \mathrm{~S}$; the temperature limits lie between $0^{\circ} \mathrm{C}$ and about $20^{\circ} \mathrm{C}$ (Schütz, 1963). Below $5^{\circ} \mathrm{C}$, the polyps frequently transform into a hibernating, non-active form, especially if the food supply is insufficient.

After adapting the hydroids stepwise to experimental conditions (steps of $5{ }^{\circ} \mathrm{C}$ and $5 \mathrm{~S} \%$ ) over $3-4$ weeks, small colonies were tied to microscope slides. When the quantity of polyps remained roughly constant over 5 days the colonies were transferred into glass vessels containing different test solutions. Following the daily check of animals, the culture water was changed in 
order to ensure that the cadmium concentration remained the same throughout the experiment. At each of the temperature-salinity combinations chosen, 4 to 7 different Cd concentrations were used. Standard solutions were prepared 10-14 days in advance and kept in polyethylene bottles at corresponding temperatures. Over that period, unspecific Cd absorption to the walls of the storage bottles was less than $0.5 \%$ (method: labelling with ${ }^{115 \mathrm{~m}} \mathrm{Cd}$ ).

Cadmium effects after 7 days of exposure were assessed in terms of hydranth retraction rates. For establishing mean effective doses $\left(\mathrm{ED}_{50}\right)$, Probit Analysis was used. This method requires a normal distribution of individual minimal effective doses. The logarithms of the $\mathrm{Cd}$ doses followed a pattern of normal distribution; thus we obtained an asymmetric standard deviation after transferring the logarithmic results to a scale of natural numbers.

In addition to an exact determination of the mean effective dose, the Probit Analysis provides information on the homogeneity of the material studied. This was verified by Chi-square test. The primary evaluation step was a graphic approach followed by reiterative approximations.

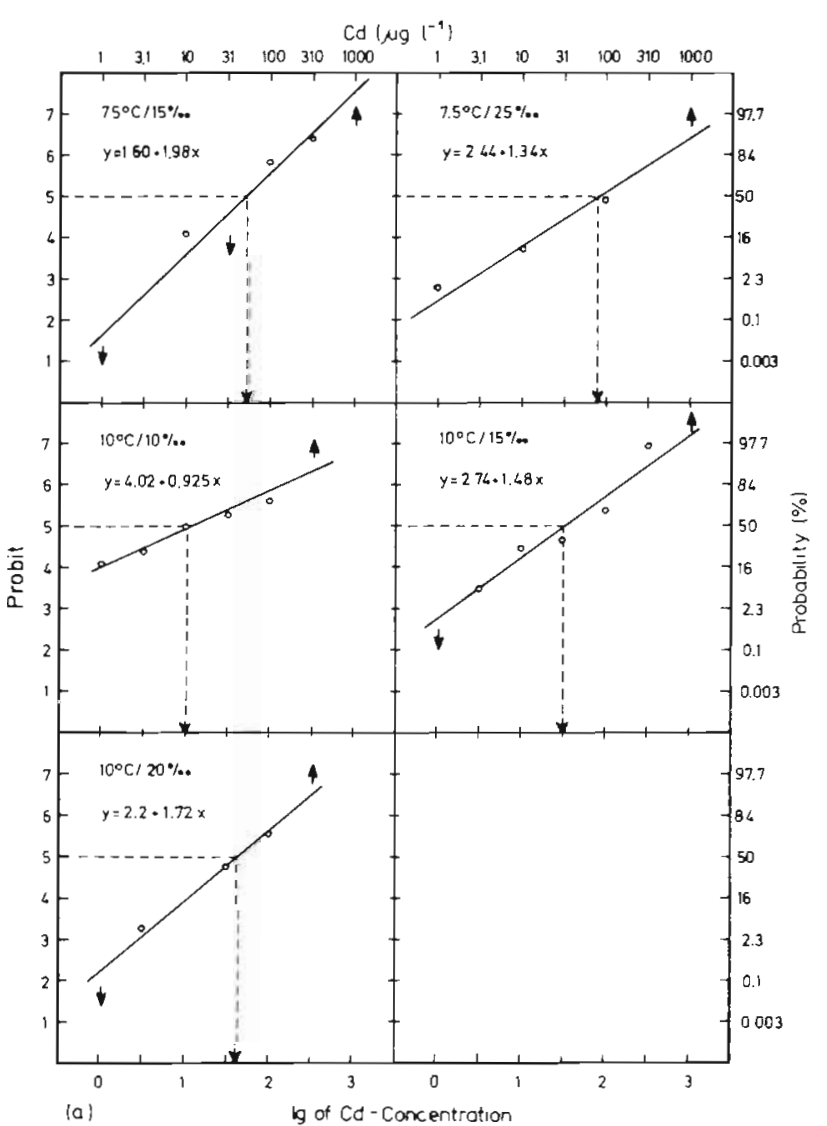

For accumulation tests we used genetically uniform material obtained by asexual reproduction of a single polyp colony. Secondary colonies were grown on glass slides in 15-1 glass aquaria at corresponding temperature-salinity conditions. The water was constantly cleaned by means of a biological filter (Fischer, in press; for review see Kinne, 1976, pp. 122-134). Every 2 days the colonies were fed 2-3-day old nauplii of Artemia salina. The water used for accumulation experiments was taken from the culture aquaria and passed through $0.45-\mu \mathrm{m}$ membrane filters. For experiments, $\mathrm{CdCl}_{2}$ in $0.01 \mathrm{n} \mathrm{HCl}$ was tracered with ${ }^{115 \mathrm{~m}} \mathrm{Cd}$.

After 7 or 10 days of exposure the hydroids were rinsed with distilled water for $30 \mathrm{~s}$ and then preserved for 2 days in distilled water containing $15 \%$ formaldehyde. Their radioactivity was measured in the Automatic Gamma Sample Analyzer BF 5000G1. Cd-concentrations refer to dry weight.

\section{RESULTS}

The $\log E_{50}$ values calculated after reiterative approximation (Fig. 1) are summarized in Table 1.

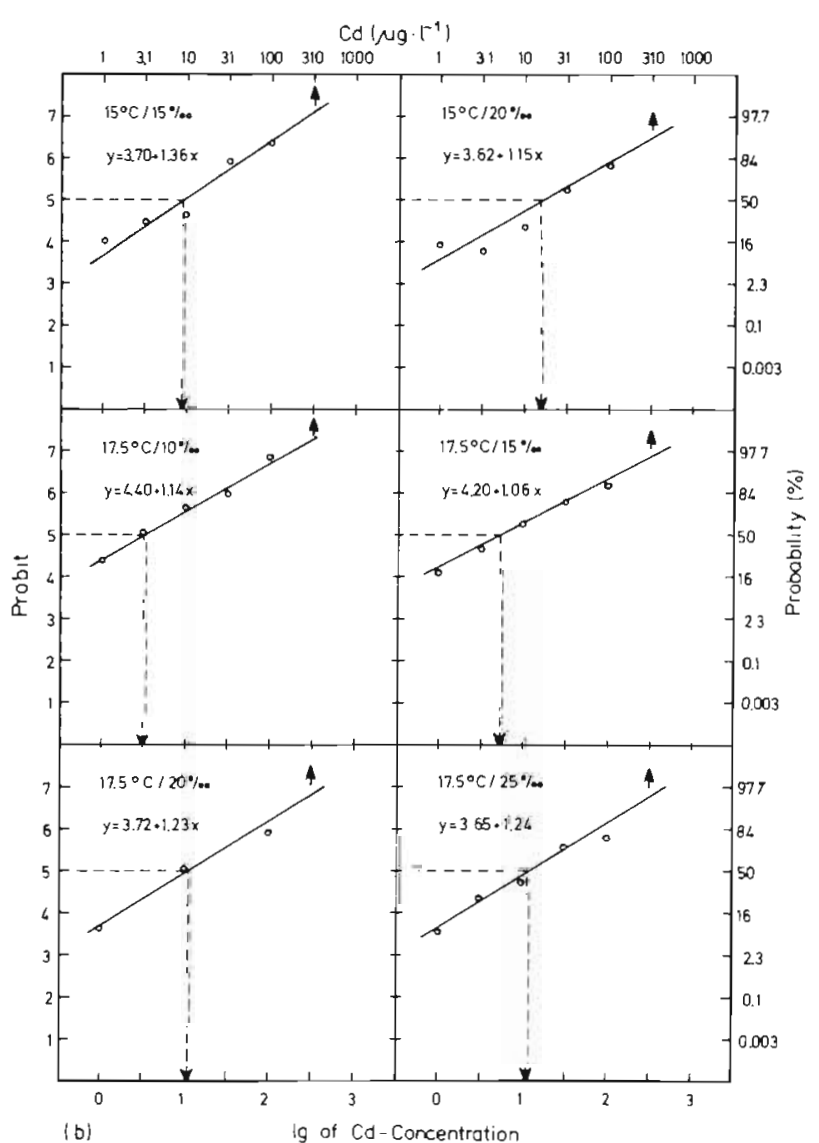

Fig. 1. Laomedea loveni. Percent retraction of hydranths at different intensities of salinity, temperature and cadmium stress after 7 days of exposure. Probability net. Regression lines reveal mean effective doses $\left(E D_{50}\right)$ at probit $5=50 \%$ probability 
Table 1 Laomeded loveni. Logarithms of mean effective doses $\left(\mathrm{ED}_{50}\right)$ of cadmium and their standard deviations at different temperature-salinity-combinations. Exposure time: 7 days. The number of Cd-concentrations tested is indicated in brackets. The values of Chi-square represent the validity of estimates. Error probability equals $5 \%\left({ }^{+}\right)$or $1 \%\left({ }^{++}\right)$, respectively

\begin{tabular}{|c|c|c|c|c|}
\hline$\% \mathrm{~S}$ & 7.5 & 10 & 15 & 17.5 \\
\hline 10 & & $\begin{array}{c}(6) \\
1.0605 \pm 0.0817 \\
x^{2}=3.3239^{++}\end{array}$ & & $\begin{array}{c}(6) \\
0.4864 \pm 0.1157 \\
x^{2}=0.9331^{++}\end{array}$ \\
\hline 15 & $\begin{array}{c}(6) \\
1.7154 \pm 0.0826 \\
x^{2}=11.7344^{+}\end{array}$ & $\begin{array}{c}(7) \\
1.5254 \pm 0.0532 \\
x^{2}=12.8884^{+}\end{array}$ & $\begin{array}{c}(6) \\
0.9586 \pm 0.0937 \\
x^{2}=5.3707^{++}\end{array}$ & $\begin{array}{c}(6) \\
0.7504 \pm 0.1117 \\
x^{2}=2.4590^{++}\end{array}$ \\
\hline 20 & & $\begin{array}{c}(5) \\
1.6235 \pm 0.0435 \\
x^{2}=3.3569^{++}\end{array}$ & $\begin{array}{c}(6) \\
1.2013 \pm 0.0576 \\
x^{2}=8.2210^{++}\end{array}$ & $\begin{array}{c}(4) \\
1.0435 \pm 0.0769 \\
x^{2}=4.7017^{++}\end{array}$ \\
\hline 25 & $\begin{array}{c}(4) \\
1.9042 \pm 0.0911 \\
x^{2}=2.6794^{++}\end{array}$ & & & $\begin{array}{c}(6) \\
1.0927 \pm 0.0623 \\
x^{2}=8.1179^{++}\end{array}$ \\
\hline
\end{tabular}

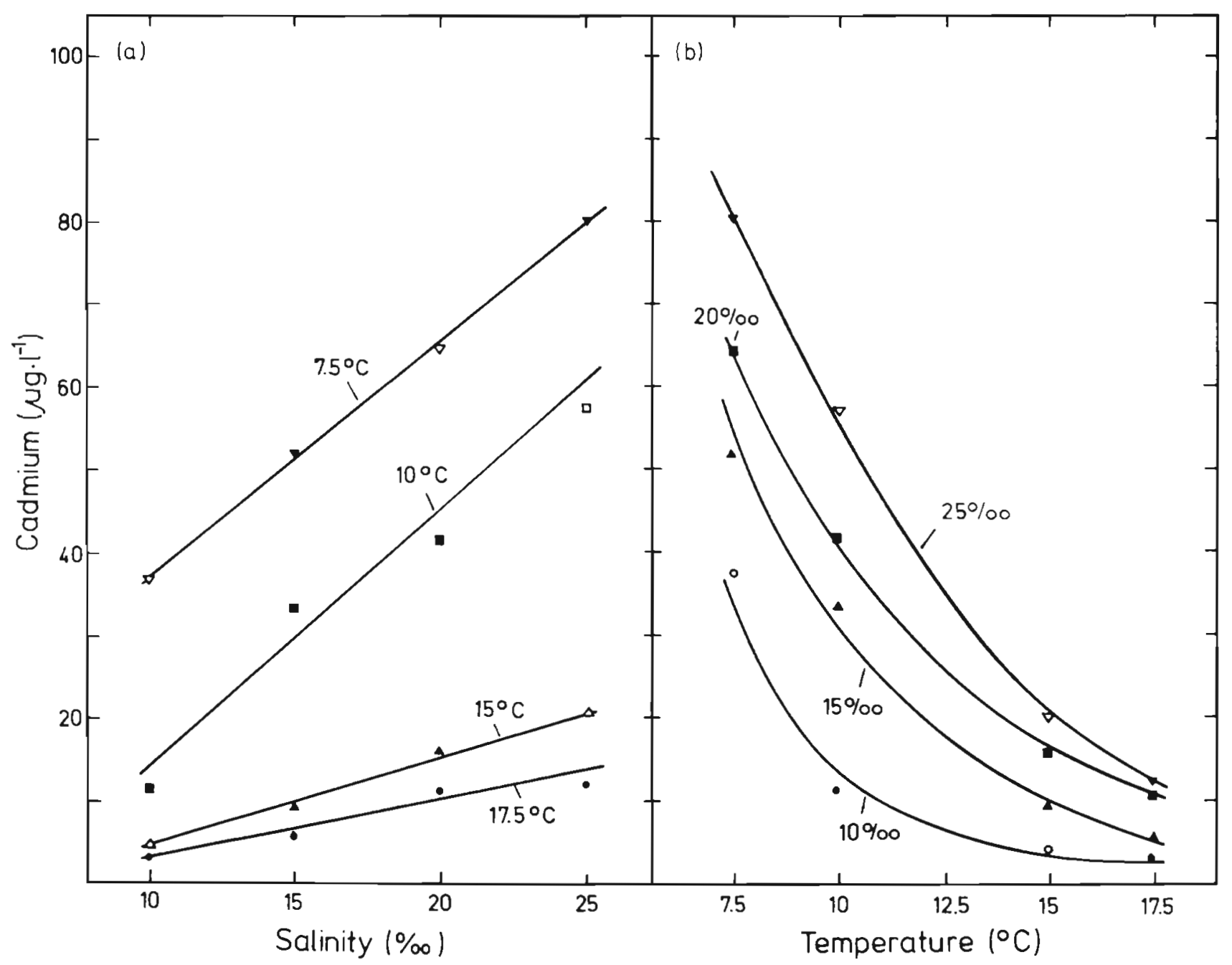

Fig. 2. Laomedea loveni. Dependence of $7 \mathrm{~d} \mathrm{ED}_{50}$-values on salinity (a) and temperature (b). Open circles: values calculated by reiterative approximation 
Table 2. Laomedea loveni. Concentrations of cadmium $\left(\mu \mathrm{g} \mathrm{l}^{-1}\right)$ inducing irreversible retraction of $50^{\circ} \%$ of polyps into hydrothecs within 7 days of exposure at different temperature-salinity-combinations. Mean values and standard deviations. Figures in brackets: calculated values. Coefficients of correlation are significant at the $1 \%\left({ }^{++}\right)$or $5 \%$ level $\left({ }^{+}\right)$

\begin{tabular}{|c|c|c|c|c|c|}
\hline$\%$ S S & 7.5 & 10 & $\begin{array}{l}{ }^{\circ} \mathrm{C} \\
15\end{array}$ & 17.5 & \\
\hline 10 & $(37.4)$ & $\begin{array}{r}+2.38 \\
11.49 \\
-1.97\end{array}$ & $(4.28)$ & $\begin{array}{r}+0.91 \\
3.06 \\
-0.74\end{array}$ & $r=-0.86597$ \\
\hline 15 & $\begin{array}{r}+10.88 \\
51.93 \\
-9.00\end{array}$ & $\begin{array}{r}+4.37 \\
33.53 \\
-3.87\end{array}$ & $\begin{array}{r}+2.19 \\
9.09 \\
-1.76\end{array}$ & $\begin{array}{r}+1.65 \\
5.63 \\
-1.28\end{array}$ & $\mathrm{r}=-0.97826^{+}$ \\
\hline 20 & (64.9) & $\begin{array}{r}+4.42 \\
42.03 \\
-4.01\end{array}$ & $\begin{array}{r}+2.25 \\
15.90 \\
-1.98\end{array}$ & $\begin{array}{r}+2.14 \\
11.05 \\
-1.79\end{array}$ & $r=-0.99132^{++}$ \\
\hline \multirow[t]{2}{*}{25} & $\begin{array}{r}+18.72 \\
80.20 \\
-15.17\end{array}$ & $(57.3)$ & $(20.44)$ & $\begin{array}{r}+1.91 \\
12.38 \\
-1.65\end{array}$ & $\mathrm{r}=-0.99031^{++}$ \\
\hline & $r=0.99954^{++}$ & $\mathrm{r}=0.98527^{++}$ & $r=0.99697^{++}$ & $I=0.97422^{++}$ & $\begin{array}{l}\text { coefficients } \\
\text { of } \\
\text { correlation }\end{array}$ \\
\hline
\end{tabular}

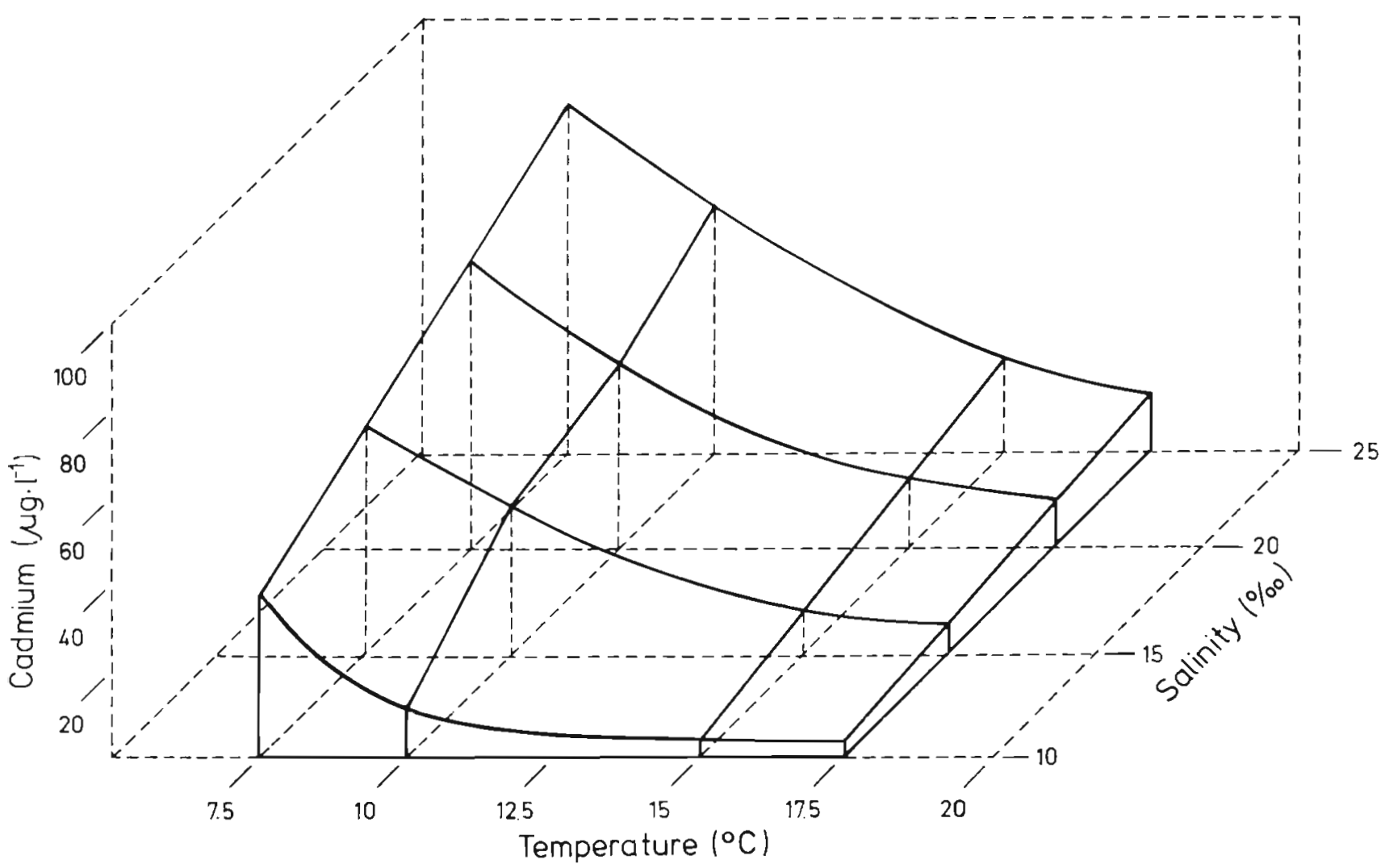

Fig. 3. Laomedea loveni. 50\% retraction of polyps due to sea water contaminated with cadmium at different combinations of temperature and salinity. Time of exposure: 7 days

After transformation to a natural number scale we obtained the actual ED $_{50}$ values with asymmetric standard deviations listed in Table 2. The values in brackets are calculated $E_{50}$ concentrations resulting from subsequent regression analysis on the basis of experi- mental results. In Figure 2 these are marked with open symbols.

The relation between $\mathrm{ED}_{50}$ values and salinity is representable by straight lines: the tolerance limits rise with increasing salinity. In contrast, the tempera- 
ture dependency of Cd tolerance is inverse: the resistance of Laomedea loveni decreases with rising temperature, the relationship being logarithmic. At $7.5^{\circ} \mathrm{C}$ and $25 \% \mathrm{~S}$, the tolerance limit of $80.2 \mu \mathrm{g} \mathrm{Cd}^{-1}$ is roughly 25 times higher than the limit of $3.06 \mu \mathrm{g} \mathrm{Cd} \mathrm{C}^{-1}$ at $17.5^{\circ} \mathrm{C}$ and $10^{\circ} \% \mathrm{~S}$ (Table 2). Figure 3 demonstrates the combined influence of temperature and salinity on $\mathrm{Cd}$ tolerance limits. This type of representation clearly shows the modifying influence of these two environmental factors on the susceptibility of $L$. loveni to $\mathrm{Cd}$ : low salinities and high temperatures lower the tolerance limit. At high salinities and low temperatures the limit is much higher.

In order to assess the effect of temperature on $\mathrm{Cd}$ accumulation, tests were carried out after adding $1.2 \mu \mathrm{g}$ $\mathrm{Cd}^{-1}$ (Table 3 ). These tests clearly show a more pronounced accumulation at higher temperatures. The influence of salinity on $\mathrm{Cd}$ accumulation was tested by exposing polyp colonies at $15^{\circ} \mathrm{C}$ in $10 \% \mathrm{~S}$ and $35 \% \mathrm{~S}$

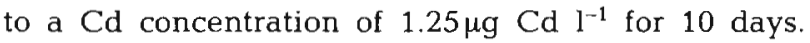
Every 2 days the water was changed and the hydroids were fed. An influence of salinity on Cd accumulation could not be demonstrated (Table 3 ).

\section{PISCUSSION AND CONCLUSIONS}

Where ecologically valid conclusions are sought, only sensitive species are suitable as test organisms for toxic substances. Marine hydroid polyps respond sensitively to heavy metals (Karbe, 1972). Laomedea loveni responds even to $\mathrm{Cd}$ concentrations in the low $\mu \mathrm{g} \mathrm{l}^{-1}$-range. A suitable criterion for assessing Cd toxicity is the irreversible retraction of $50 \%$ of the polyps $\left(E_{50}\right)$. For Eirene viridula Karbe (1972) was also able to characterize other sublethal effects (thickening and shortening of tentacles, followed by a reduction of polyp colonies) which could be identified macroscopically. These phenomena, however, could not be regularly observed in $L$. loveni. The possible reason for this seems to be that, under adverse environmental condi-
Table 3. Laomedea loveni. Effects of temperature and salinity on the degree of cadmium accumulation

\begin{tabular}{|cccccc|}
\hline $\begin{array}{c}\text { Sali- } \\
\text { nity } \\
(\%)\end{array}$ & $\left.\begin{array}{c}\text { Tempe- Time of } \\
\text { rature }\end{array}{ }^{\circ} \mathrm{C}\right)$ & $\begin{array}{c}\text { Cxposure } \\
\text { (days) }\end{array}$ & $\begin{array}{c}\text { in } \\
\text { water } \\
\left(\mu g \mathrm{l}^{-1}\right)\end{array}$ & $\begin{array}{c}\text { in } \\
\text { animal } \\
\left(\mu \mathrm{g} \mathrm{g}^{-1} \mathrm{~d} r y\right. \\
\text { weight) }\end{array}$ & $\begin{array}{c}\text { Number } \\
\text { of pooled } \\
\text { colonies }\end{array}$ \\
\hline 15 & 5 & 7 & 1.2 & 0.35 & 3 \\
15 & 10 & 7 & 1.2 & 0.48 & 3 \\
15 & 15 & 7 & 1.2 & 0.64 & 3 \\
15 & 20 & 7 & 1.2 & 0.83 & 3 \\
10 & 15 & 10 & 1.25 & 0.92 & 4 \\
35 & 15 & 10 & 1.25 & 0.70 & 4 \\
\hline
\end{tabular}

tions, polyps of $L$. loveni withdraw into the hydrothec whereas $E$. viridula (although belonging to the suborder Thecata) has a reduced hydrothec.

The lowest $\mathrm{Cd}$ concentration effecting retraction in Laomedea loveni is about $3 \mu \mathrm{g}^{-1}$ at $17.5^{\circ} \mathrm{C}$ and $10^{\%} \% \mathrm{~S}$. The Cd concentrations found in the Baltic Sea (average: $0.17-0.22 \mu \mathrm{g} \mathrm{l}^{-1}$; Kremling, 1973) slightly exceed the values considered to be normal in the open sea $\left(0.11 \mu \mathrm{g} \mathrm{l}^{-1}\right.$; Horne, 1969). However, in more contaminated coastal areas considerably higher values may be observed. Butterworth et al. (1972) measured concen-

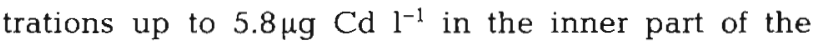
Severn Estuary. In this estuary, $\mathrm{Cd}$ concentrations lie within the range of values that caused definite injuries to $L$. loveni. Cumulative effects of other toxic substances may, of course, further lower the critical $\mathrm{Cd}$ limit.

Considerable differences are found when comparing the tolerance limits established for Laomedea loveni with those for other species. Table 4 lists values for other species obtained for periods of time comparable to those used with $L$. loveni. Further data for acute toxicity of Cd to marine animals have been presented by Eisler (1971), O'Hara (1973), Ahsanullah (1976), Negilski (1976), Ahsanullah and Arnott (1978), Nimmo et al. (1978), Schreck and Lorz (1978), Weis and Weis

Table 4. Threshold values for cadmium toxicity in different animal species. Test periods similar as with $L$. loveni

\begin{tabular}{|c|c|c|}
\hline Species & $\begin{array}{l}\text { 'Threshold value' } \\
\left(\mu \mathrm{Cd} \mathrm{l}^{-1}=\mathrm{ppb} \mathrm{Cd}\right)\end{array}$ & Source \\
\hline Fundulus heteroclitus & $192 \mathrm{~h} \mathrm{LD}_{50} 15,000-80,000$ & Eisler (1971) \\
\hline Artemia salina & $168 \mathrm{~h} \mathrm{LD} \mathrm{D}_{50} 50,000$ & $\begin{array}{l}\text { Brown and } \\
\text { Ahsanullah (1971) }\end{array}$ \\
\hline Uca pugilator & $144 \mathrm{hLD}_{50} 4,000-51,000$ & O'Hara (1973) \\
\hline Ophryotrocha sp. & $168 \mathrm{hLD}_{50} 4,000$ & $\begin{array}{l}\text { Brown and } \\
\text { Ahsanullah (1971) }\end{array}$ \\
\hline Eirene viridula & $100-300$ & Karbe (1972) \\
\hline Clava multicornis & $168 \mathrm{~h} \mathrm{ED}_{50} 250$ & Fischer (1978) \\
\hline Campanularia flexuosa & $264 \mathrm{~h} \mathrm{ED}_{50} 110-280$ & Stebbing (1976) \\
\hline Laomedea loveni & $168 \mathrm{~h} \mathrm{ED}_{50} 3-80$ & Present paper \\
\hline
\end{tabular}


(1978). Differences in Cd tolerance of different species may be related to their permeabilities and rates of heavy-metal accumulation as well as to different sensitivities of their enzyme systems (Vallee and Ulmer, 1972). Another possible reason for certain species being more resistant than others may lie in their ability to synthesize special proteins or related molecules which can bind heavy metals, thus playing an important part in decontamination (for vertebrates consult the review by Webb, 1975; Olafson and Thompson, 1974; Lee et al., 1977; Overnell et al., 1977; for invertebrates, Noel-Lambot, 1976; Coombs and George, 1977; Chou et al, 1978).

The importance of considering environmental factors when establishing critical values for the toxicity of $\mathrm{Cd}$ in sea water has been demonstrated, for examples by Eisler (1971), O'Hara (1973), von Westernhagen et al. $(1974,1975)$, Rosenberg and Costlow (1976), Sullivan (1977), Voyer et al. (1977), Weis and Weis (1978), Lehnberg und Theede (1979). The susceptibility to $\mathrm{Cd}$ of the hydroid polyp Laomedea loveni significantly depends on temperature and salinity. This fact confirms the hypothesis that marine organisms living near their distributional limits in estuaries or in the Baltic Sea tend to suffer at considerably lower pollution levels than those living under optimal environmental conditions. Consequently, critical toxicity limits established under normal marine conditions may not automatically be applicable to conditions prevailing in estuaries or in the Baltic Sea. This may also explain the more pronounced diminution of marine and/or limnic organisms due to toxic substances in brackish waters, where the organisms are already living in conditions close to their tolerance limits.

The toxicity experiments conducted pose further questions, for instance: what are the Cd quantities accumulated under the different test conditions, and what are the intracellular concentrations that lead to the toxic effects observed? Furthermore, experiments on $\mathrm{Cd}$ intake from food have still to be carried out.

\section{LITERATURE CITED}

Ahsanullah, M. (1976). Acute Toxicity of cadmium and zinc to seven invertebrate species from western Port, Victoria. Aust. J. mar. Freshwat. Res., 27, 187-196.

Ahsanuliah, M. and Arnott, G. H. (1978). Acute toxicity of copper, cadmium, and zinc to larvae of the crab Paragrapsus quadridentatus ( $\mathrm{H}$. Milne Edwards), and implications for water quality criteria. Aust. J. mar. Freshwat. Res., 29, $1-8$

Brown, B. and Ahsanullah, M. (1971). Effect of heavy metals on mortality and growth. Mar. Pollut. Bull., 2, 182-187.

Butterworth, J., Lester, P. and Nickless, G. (1972). Distribution of heavy metals in the Severn Estuary. Mar. Pollut. BuIl., 3, $72-74$.

Chou, C. L., Uthe, J. F. and Zook, E. G. (1978). Polarographic studies on the nature of cadmium in scallop, oyster and lobster. J. Fish. Res. Bd Can., 35, 409-413.

Connor, P. M. (1972). Acute toxicity of heavy metals to some marine larvae. Mar. Pollut. Bull., 3, 190-192.

Coombs, T. L. and George, S. G. (1977). Mechanisms of immobilization and detoxication of metals in marine organisms. Proc. mar. bio. Symp., 12, 179-187.

Eisler, R. (1971). Cadmium poisoning in Fundulus heteroclitus (Pisces: Cyprinodontidae) and other marine organisms. J. Fish. Res. Bd Can., 28, 1225-1234.

Erlenkeuser, H., Suess, E. and Willkomm, H. (1974). Industrialization affects heavy metal and carbon isotope concentrations in recent Baltic Sea sediments. Geochim. cosmochim. Acta, 38, 823-842.

Fischer, $H$. (in press). Hydroids in biotest: Clava multicornis exposed to cadmium. Kieler Meeresforsch., Sonderheft 4.

Förstner, U. und Müller, G. (1974). Schwermetalle in Flüssen und Seen als Ausdruck der Umweltverschmutzung, Springer-Verlag, Berlin.

Horne, R. A. (1969). Marine Chemistry, Wiley Interscience, New York.

Jones, M. B. (1975). Synergistic effects of salinity, temperature and heavy metals on mortality and osmoregulation in marine and estuarine isopods (Crustacea). Mar. Biol., 30, $13-20$.

Karbe, L. (1972). Marine Hydroiden als Testorganismen zur Prüfung der Toxizität von Abwasserstoffen. Die Wirkung von Schwermetallen auf Kolonien von Eirene viridula. Mar. Biol., 12, 316-328

Kinne, O. (1970). Temperature: invertebrates. In O. Kinne (Ed.), Marine Ecology, Vol. I, Environmental Factors, Part 1. Wiley, London. pp. 407-514.

Kinne, O. (1971). Salinity: invertebrates. In O. Kinne (Ed.) Marine Ecology, Vol. I, Environmental Factors, Part 2. Wiley, London. pp. 821-995.

Kinne, O. (1976). Cultivation of marine organisms: water quality management and technology. In O. Kinne (Ed.), Marine Ecology, Vol. III, Cultivation, Part 1. Wiley, London. pp. 19-300.

Kremling, K. (1973). Voltametrische Messungen über die Verteilung von Zink, Cadmium, Blei und Kupfer in der Ostsee. Kieler Meeresforsch., 29, 77-83.

Lee, S. S., Mate, B. R., von der Trenck, K. T., Rimerman, R. A. and Buhler, D. R. (1977). Metallothionein and the subcellular localization of mercury and cadmium in the california sea lion. Comp. Biochem. Physiol., 57 C, 45-53.

Lehnberg, W. und Theede, H. (1979). Kombinierte Wirkungen von Temperatur, Salzgehalt und Cadmium auf Entwicklung, Wachstum und Mortalität der Larven von Mytilus edulis aus der westlichen Ostsee. Helgoländer wiss. Meeresunters., 32, 179-199.

Negilski, D. S. (1976). Acute toxicity of zinc, cadmium and chromium to the marine fishes, yellow-eye mullet (Aldrichetta forsteri C. \& V.) and small-mouthed hardyhead (Atherinasoma microstoma Whitley). Aust. J. mar. Freshwat. Res., 27, 137-149.

Nimmo, D. R., Ringby, R. A., Bahner, L. H. and Sheppard, J. M. (1978). The acute and chronic effects of cadmium on the estuarine mysid, Mysidopsis bahia. Bull. Environm. Contam. Toxicol., 19, 80-85.

Noël-Lambot, F. (1976). Distribution of cadmium, zinc and copper in the mussel Mytilus edulis. Existence of cadmium-binding proteins similar to metallothioneins. Experientia, 32 (3), 324-326. 
O'Hara, J. (1973). Cadmium uptake by fiddler crabs exposed to temperature and salinity stress. J. Fish. Res. Bd Can., 30, 846-848.

Olafson, R. W. and Thompson, J. A. J. (1974). Isolation of heavy metal binding proteins from manine vertebrates. Mar. Biol., 28, 83-86.

Olson, K. R. and Harrel, R. C. (1973). Effect of salinity on acute toxicity of mercury, copper and chromium for Rangia cuneata (Pelecypoda, Mactridae). Contr. Mar. Science, 17, 9-13.

Overnell, J., Davidson, I. A. and Coombs, T. L. (1977). A cadmium-binding glycoprotein from the liver of the plaice (Pleuronectes platessa). Biochem. Soc. Transact, 5, 1-3.

Phillips, J. H. (1977). The use of biological indicator organisms to monitor trace metal pollution in marine and estuarine environments - a review. Environ. Pollut., 13, $281-317$.

Pickering, Q. H. and Gast, M. H. (1972). Acute and chronic toxicity of cadmium to the fathead minnow (Pimephales promelas). J. Fish. Res. Bd Can., 29, 1099-1106.

Pickering, Q. H. and Henderson, C. (1966). The acute toxicity of some heavy metals to different species of warmwater fishes. Air \& Wat. Pollut., 10, 453-463.

Rosenberg, R. and Costolow, J. D., Jr, (1976). Synergistic effects of cadmium and salinity combined with constant and cycling temperatures on the larval development of two estuarine crab species. Mar. Biol., 38, 291-303.

Schreck, C. B. and Lorz, H. W. (1978). Stress response of coho salmon (Oncorhynchus kisutch) elicited by cadmium and copper and potential use of cortisol as an indicator of stress. J. Fish. Res. Bd Can., 35, 1124-1129.

Schütz, L. (1963). Okologische Untersuchungen über die
Benthosfauna im N.-O.-Kanal. I. Autökologie der sessilen Arten. Int. Revue ges. Hydrobiol., 48, 361-418.

Stebbing, A. R. D. (1976). The effects of low metal levels on a clonal hydroid. J. mar. biol. Ass. U. K, 56, 977-994.

Sullivan, J. K. (1977). Effects of salinity and temperature on the acute toxicity of cadmium to the estuarine crab Paragrapsus gaimardii (Milne Edwards). Aust. J. mar. Freshwat. Res., 28, 739-743.

Vallee, B. L. and Ulmer, D. D. (1972). Biochemical effects of mercury, cadmium and lead. A. Rev. Biochem., 41, 91-128.

Vervoort, W. (1946). Hydrozoa (C1), A Hydropolypen. In H. Boschma (Ed.), Fauna van Nederland, XIV. A. W. Sijthoff's Uitgeversmaatschappij N. V., Leiden. pp. 1-336.

Voyer, R. A., Wentworth, C. E., Barry, E. P. and Hennekey, R. J. (1977). Viability of embryos of the winter flounder Pseudopleuronectes americanus exposed to combinations of cadmium and salinity at selected temperatures. Mar. Biol., 44, 117-124.

Webb, M. (1975). Metallothionein and the toxicity of cadmium. In A. D. McIntyre and C. F. Mills (Eds), Ecological Toxicology Research. Plenum Press, London. pp. 177-186.

Weis, P. and Weis. J. S. (1978). Methylmercury inhibition of fin regeneration in fishes and its interaction with salinity and cadmium. Estuar. Coast. Mar. Sci. 6, 327-334.

Westernhagen, $H$. von, Dethlefsen, $V$. and Rosenthal, $H$. (1975). Combined effects of cadmium and salinity on development and survival of garpike eggs. Helgoländer wiss. Meeresunters, 27, 268-282.

Westernhagen, $H$. von, Rosenthal, H. and Sperling, K.-R. (1974). Combined effects of cadmium and salinity on development and survival of herring eggs. Helgoländer wiss. Meeresunters., 26, 416-433.

This paper was submitted to the editor; it was accepted for printing on May 14, 1979. 